\title{
GASTRIC SECRETION. II. ABSORPTION OF RADIOACTIVE SODIUM FROM POUCHES OF THE BODY AND ANTRUM OF THE STOMACH OF THE DOG
}

\author{
By OLIVER COPE, WALDO E. COHN, AND ADDISON G. BRENIZER, JR. \\ (From the Surgical Research and John Collins Warren Laboratories of Harvard University, \\ at the Massachusetts General Hospital, Boston)
}

(Received for publication August 7, 1942)

The biochemical process by which cells of the stomach produce hydrochloric acid remains a mystery. Although the approximate concentration of the acid has been calculated on indirect evidence, the exact concentration as it is secreted has not been determined in any animal. This is despite the fact that, over a period of many years, increasingly precise observations have been made.

The difficulty confronting observers is that the same area of the stomach which secretes the hydrochloric acid also forms pepsin and mucin, and allows the passage of certain inorganic electrolytes and urea between the blood and stomach lumen. Little light has been thrown on this subject by analyses of the gastric contents of the stomach, since swallowed saliva and regurgitated secretions from the duodenum inconstantly contaminate the contents. Gastric pouches were first conceived to discount the inaccuracies of studying gastric contents, and indeed, examination of fluid collected from a pouch of the stomach of an experimental animal yields accurate information. It is frequently assumed, however, that this fluid from pouches represents true secretion. No account is taken of a possible concomitant absorption of water or electrolytes from the gastric lumen into the lymphatics or blood stream. Unless reabsorption can be excluded, the fluid within a pouch does not represent secretion but the resultant of secretion and absorption.

During the course of experiments on the effect of the osmotic pressure of gastric pouch contents on the volume of secretion (1), it became obvious that absorption from the pouch must be controlled. It is known that some substances are absorbed from the stomach in small quantities (2), but it is not known whether all of the observed absorption takes place from the antrum or from the body of the stomach. In contrast to the body of the stomach which secretes the hydrochloric acid, the antrum secretes a neutral mucoid liquid. Since the main part of absorption from the gastrointestinal tract takes place in the intestine, the contents of which are neutral or alkaline, it is considered possible that most or all of the absorption attributed to the stomach might well occur in the antrum.

Recently, Eisenman et al. (3) have reported the absorption of various radioactive isotopes from the stomach, but no attempt to differentiate between antrum and body was reported.

The experiments reported in this and the subsequent paper (4) were devised, not only to examine the conditions controlling absorption from the stomach, but also to judge the relative absorptive powers of the antrum and body of the stomach.

\section{METHODS}

Dogs with a pouch of either the body or antrum of the stomach were used. Pouches of the body were made in the manner previously described (5). There is no leakage from these pouches. Fluid can be introduced or withdrawn from the pouch by passing a catheter through the stoma in the flank.

In order to maintain the chloride balance, ammonium and sodium chloride are given by stomach tube to the dogs at regular intervals throughout the day. One thousand to $1500 \mathrm{cc}$. of acid secretion are lost daily from the pouch. This amounts to nearly one-third of the available fluid volume of the dog. Since the chloride concentration of the secretion is higher than that of plasma or lymph, it is obvious that such animals would be rapidly depleted of chloride if this electrolyte were not returned constantly. The gastric fluid collected from the pouch is not returned to the animal because it is often alkaline from an excess of sodium bicarbonate solution, put in after the previous emptying. Neutralization of the gastric secretion is necessary over any extended period to prevent peptic digestion of the pouch wall. Bicarbonate solution is omitted the afternoon before an experiment.

Pouches of the antrum were made by a two stage technic. At a first operation, the antrum. was divided from the body of the stomach. Both the anterior and posterior walls of the stomach were divided from the incisura to 
the opposite point on the greater curvature. The terminal branches of both vagus nerves which pass to the antrum (5), and the sympathetic nerves which pass with the vessels, were spared. The open end of the antrum was closed to form the antral pouch. The open end of the body was anastomosed to the upper jejunum. At a second operation, 3 or more weeks later, when the suture lines of the first were well healed, the duodenum was divided $0.5 \mathrm{~cm}$. distal to the pyloric ring. The duodenal stump was turned in. The pylorus with the cuff of duodenum was then pulled through a stab wound in the right flank just below the costal margin, forming the stoma of the pouch. The only difficulty encountered in the operative procedures was in obtaining sufficient mobility of the antrum without dividing nerves and vessels. The nerve supply to the pylorus was sacrificed.

The secretion from such a pouch is thickly mucoid; its volume is small and grossly not increased during diges-

TABLE I

The concentration of $\mathrm{Na}^{24}$ in the blood serum at intervals after its introduction into the pouches of dogs with body pouches, and the chemical determinations on gastric contents and blood serum

Where two sets of figures are given for both gastric contents and blood serum, the top figure represents the determination on contents and blood removed immediately prior to the introduction of the $\mathrm{Na}^{24} \mathrm{Cl}$ solution; the bottom figure (in italics) represents the determination made on the contents and blood removed at the end of the experiment. Where only one figure is given for the blood, a single blood sample was removed in the middle of the experiment. Dog number 1: weight $21.7 \mathrm{kgm}$., plasma volume $854 \mathrm{cc}$., interstitial fluid volume $4538 \mathrm{cc}$., available fluid $5621 \mathrm{cc}$. Dog number 2 : weight $21.8 \mathrm{kgm}$., plasma volume $1064 \mathrm{cc}$., interstitial fluid volume $4891 \mathrm{cc}$., available fluid $5955 \mathrm{cc}$. Dog number 3 : weight $19.4 \mathrm{kgm}$., plasma volume 796 cc., interstitial fluid 5190 cc., available fluid 6178 cc.

\begin{tabular}{|c|c|c|c|c|c|c|c|c|c|c|c|c|c|}
\hline \multirow{3}{*}{$\begin{array}{c}\text { Experi- } \\
\text { ment } \\
\text { number }\end{array}$} & \multirow{3}{*}{$\begin{array}{l}\mathrm{NaCl} \text { concentration } \\
\text { State of pouch }\end{array}$} & \multirow{2}{*}{\multicolumn{4}{|c|}{$\frac{\mathrm{Na}^{2 \mathrm{H}}}{\mathrm{Blood} \text { serum }}$}} & \multicolumn{3}{|c|}{ Gastric content } & \multicolumn{4}{|c|}{ Blood serum } & \multirow{3}{*}{ Date } \\
\hline & & & & & & \multirow{2}{*}{$\mathrm{pH}$} & \multirow{2}{*}{$\mathrm{Cl}$} & \multirow{2}{*}{$\begin{array}{l}\text { Total } \\
\text { base }\end{array}$} & \multirow{2}{*}{$\mathrm{Cl}$} & \multirow{2}{*}{$\mathrm{CO}_{2}$} & \multirow{2}{*}{$\begin{array}{l}\text { Total } \\
\text { base }\end{array}$} & \multirow{2}{*}{$\mathbf{N a}$} & \\
\hline & & $15^{\prime}$ & $30^{\prime}$ & $60^{\circ}$ & $120^{\prime}$ & & & & & & & & \\
\hline $\begin{array}{c}\text { Dog } 1 \\
1\end{array}$ & $\begin{array}{l}0.9 \text { per cent } \\
\text { Secreting }\end{array}$ & 0.5 & p.p.m. & per cc. & & & m.eq. & per $L$. & & m.eq. & per $L$. & & December 18,1940 \\
\hline 2 & Seereting & 1.5 & 5.0 & 2.8 & & $\begin{array}{l}1.3 \\
1.4\end{array}$ & $\begin{array}{l}130 \\
144\end{array}$ & & $\begin{array}{l}112 \\
116\end{array}$ & & $\begin{array}{l}157 \\
159\end{array}$ & $\begin{array}{l}152 \\
152\end{array}$ & February 5, 1941 \\
\hline 3 & Secreting & & & 0.6 & 3.2 & $\begin{array}{l}1.0 \\
1.2\end{array}$ & $\begin{array}{l}154 \\
156\end{array}$ & & $\begin{array}{l}100 \\
100\end{array}$ & $\begin{array}{l}32 \\
32\end{array}$ & $\begin{array}{l}155 \\
155\end{array}$ & $\begin{array}{l}145 \\
145\end{array}$ & June 5, 1941 \\
\hline 4 & Secreting & & & 3.1 & 3.6 & $\begin{array}{l}6.9 \\
1.3\end{array}$ & $\begin{array}{l}144 \\
156\end{array}$ & $\begin{array}{r}140 \\
61\end{array}$ & 68 & 59 & 146 & 138 & October 10, 1941 \\
\hline 5 & Fasting & 0.9 & 2.3 & 4.5 & & & & & & & & & January 22, 1941 \\
\hline 6 & Fasting & 2.2 & 5.0 & 9.6 & & 8.2 & 147 & 143 & $\begin{array}{l}82 \\
84\end{array}$ & $\begin{array}{l}45 \\
46\end{array}$ & $\begin{array}{l}144 \\
145\end{array}$ & $\begin{array}{l}144 \\
149\end{array}$ & February 27, 1941 \\
\hline 7 & Fasting & 2.0 & 3.6 & 8.4 & 20.5 & 2.1 & 137 & 102 & 104 & 32 & 157 & 153 & March 26, 1941 \\
\hline 8 & Fasting & & & 7.4 & 11.5 & $\begin{array}{l}2.0 \\
5.5\end{array}$ & $\begin{array}{l}152 \\
158\end{array}$ & $\begin{array}{l}135 \\
156\end{array}$ & $\begin{array}{l}108 \\
108\end{array}$ & 33 & $\begin{array}{l}152 \\
152\end{array}$ & 140 & October 1, 1941 \\
\hline 9 & $\begin{array}{l}3.1 \text { per cent } \\
\text { Secreting }\end{array}$ & & & 1.1 & 1.9 & $\begin{array}{l}1.0 \\
1.3\end{array}$ & $\begin{array}{l}157 \\
206\end{array}$ & & $\begin{array}{l}104 \\
108\end{array}$ & $\begin{array}{l}33 \\
33\end{array}$ & $\begin{array}{l}154 \\
157\end{array}$ & 145 & June 12, 1941 \\
\hline 10 & Secreting & & & 1.1 & 1.5 & $\begin{array}{l}0.9 \\
1.1\end{array}$ & $\begin{array}{l}160 \\
208\end{array}$ & & 102 & 31 & 155 & 144 & June 24, 1941 \\
\hline 11 & Secreting & & & 2.6 & 2.4 & $\begin{array}{l}1.1 \\
1.3\end{array}$ & $\begin{array}{l}156 \\
202\end{array}$ & & 110 & 26 & 157 & 144 & July 8, 1941 \\
\hline 12 & $\begin{array}{l}0.4 \text { per cent } \\
\text { Secreting }\end{array}$ & & & 2.9 & 7.3 & $\begin{array}{l}0.9 \\
1.0\end{array}$ & $\begin{array}{l}157 \\
150\end{array}$ & & 111 & 27 & 154 & 145 & July 17, 1941 \\
\hline 13 & Secreting & & & 1.9 & 5.3 & $\begin{array}{l}1.0 \\
1.1\end{array}$ & $\begin{array}{l}154 \\
147\end{array}$ & & 108 & 28 & 155 & 143 & July 25, 1941 \\
\hline
\end{tabular}


TABLE I-Continued

\begin{tabular}{|c|c|c|c|c|c|c|c|c|c|c|c|c|c|}
\hline \multirow{3}{*}{$\begin{array}{l}\text { Experi- } \\
\text { ment } \\
\text { number }\end{array}$} & \multirow{3}{*}{$\begin{array}{l}\mathrm{NaCl} \text { concentration } \\
\text { State of pouch }\end{array}$} & \multirow{2}{*}{\multicolumn{4}{|c|}{$\frac{\mathrm{Na}^{2 \mathrm{u}}}{\mathrm{Blood} \text { serum }}$}} & \multicolumn{3}{|c|}{ Gastric content } & \multicolumn{4}{|c|}{ Blood serum } & \multirow{3}{*}{ Date } \\
\hline & & & & & & \multirow{2}{*}{$\mathrm{pH}$} & \multirow{2}{*}{$\mathrm{Cl}$} & \multirow{2}{*}{$\begin{array}{l}\text { Total } \\
\text { base }\end{array}$} & \multirow{2}{*}{$\mathrm{Cl}$} & \multirow{2}{*}{$\mathrm{CO}_{2}$} & \multirow{2}{*}{$\begin{array}{l}\text { Total } \\
\text { base }\end{array}$} & \multirow{2}{*}{$\mathbf{N a}$} & \\
\hline & & $15^{\prime}$ & $30^{\circ}$ & $60^{\prime}$ & $120^{\circ}$ & & & & & & & & \\
\hline $\begin{array}{c}D o g \\
14\end{array}$ & $\begin{array}{l}0.9 \text { per cent } \\
\text { Secreting }\end{array}$ & 0.3 & 0.4 & 0.7 & & & m.eq. & $\operatorname{per} L$. & & m.eq. & $\operatorname{per} L$. & & January 22,1941 \\
\hline 15 & Secreting & 1.4 & 1.6 & 2.8 & & 1.5 & 160 & 114 & $\begin{array}{l}106 \\
106\end{array}$ & $\begin{array}{l}32 \\
35\end{array}$ & $\begin{array}{l}154 \\
158\end{array}$ & $\begin{array}{l}166 \\
167\end{array}$ & February 27, 1941 \\
\hline 16 & Secreting & & & 1.6 & 2.0 & $\begin{array}{l}1.3 \\
1.3\end{array}$ & $\begin{array}{l}140 \\
158\end{array}$ & & $\begin{array}{l}106 \\
102\end{array}$ & $\begin{array}{l}25 \\
31\end{array}$ & $\begin{array}{l}152 \\
168\end{array}$ & 147 & June 5,1941 \\
\hline 17 & Fasting & 3.3 & 7.6 & 13.2 & & & & & & & & & December 18, 1940 \\
\hline 18 & Fasting & 4.0 & 6.5 & 10.0 & & $\begin{array}{l}7.0 \\
7.6\end{array}$ & $\begin{array}{l}128 \\
160\end{array}$ & & $\begin{array}{l}90 \\
94\end{array}$ & & $\begin{array}{l}148 \\
148\end{array}$ & $\begin{array}{l}140 \\
144\end{array}$ & February 5, 1941 \\
\hline 19 & Fasting & 34.0 & 58.0 & $\mid 76.0$ & 102.0 & 7.2 & 116 & 163 & 92 & 38 & 154 & 150 & March 26, 1941 \\
\hline 20 & $\begin{array}{l}3.1 \text { per cent } \\
\text { Secreting }\end{array}$ & & & 2.8 & 4.2 & $\begin{array}{l}1.1 \\
1.4\end{array}$ & $\begin{array}{l}144 \\
218\end{array}$ & & $\begin{array}{l}106 \\
108\end{array}$ & $\begin{array}{l}29 \\
29\end{array}$ & $\begin{array}{l}157 \\
157\end{array}$ & $\begin{array}{l}145 \\
146\end{array}$ & June 12,1941 \\
\hline $\begin{array}{c}D o g \\
21\end{array}$ & $\begin{array}{l}3.1 \text { per cent } \\
\text { Secreting }\end{array}$ & & & 3.5 & 3.5 & $\begin{array}{l}1.1 \\
1.1\end{array}$ & $\begin{array}{l}147 \\
204\end{array}$ & & 112 & 25 & 161 & 151 & June 24, 1941 \\
\hline 22 & Secreting & & & 2.6 & 3.0 & $\begin{array}{l}1.1 \\
1.4\end{array}$ & $\begin{array}{l}145 \\
215\end{array}$ & & 104 & 27 & 150 & 139 & July 8,1941 \\
\hline
\end{tabular}

tion of food in the body of the stomach. The $\mathrm{pH}$ of the secretion is usually around 7 but in some animals may fall during active gastric digestion. In this case, there are a few parietal cells presumably included in the pouch. The pouch has strong muscular contractions and rarely contains more than 1 to $2 \mathrm{cc}$. In a large dog, the pouch may be made so it will contain $15 \mathrm{cc}$. The experiments were run with a catheter in place and an open syringe attached to the outer end. The fluid level in the syringe was kept a few centimeters above the pouch. The test fluid fluctuated with each period of relaxation and contraction of the pouch. With severe contractions, leakage sometimes occurred around the catheter at the stoma.

Radioactive sodium $\left(\mathrm{Na}^{24}\right)$ was prepared by bombardment of metallic sodium with deuterons. ${ }^{1}$ This was converted into $\mathrm{NaCl}$ and made up to the desired concentration with water. Measurements of radioactivity were made with the aid of a Geiger-Muller counting rate meter and a Lauritzen electroscope. All results are corrected for radioactive decay, and are expressed in arbitrary units. One unit represents one-millionth part of the ad-

1 We are indebted to Dr. B. Curtis and the crew of the Harvard cyclotron for the radioactive material used in these experiments. ministered $\mathrm{Na}^{24}$ and is represented by the symbol p.p.m. (parts per million).

In order to bathe the mucous membrane of the pouch evenly, $30 \mathrm{cc}$. of the solution containing the radioactive sodium were placed in the pouches of the body. In the antral pouches, 10 to $15 \mathrm{cc}$. were used.

The absorption of radioactive sodium was determined from the concentration observed in the blood stream. Because of the small amount of sodium actually absorbed, and some leakage in the case of the antral pouches, the estimation of the total sodium absorbed, determined by subtracting the sodium recovered in the pouch at the end of the experiment from the sodium put in at the beginning, is inaccurate. The determination of the radioactive sodium within the blood serum gave reproducible results with an error of less than 5 per cent. From these serum concentrations, and the combined plasma and interstitial fluid volumes as determined with Evans blue and thiocyanate (6), the total $\mathrm{Na}^{24}$ absorbed was calculated on the assumption that it was evenly distributed extracellularly. The small amount in the erythrocytes (7) and bone ( 8 ) is negligible.

All of the chemical determinations have been made by standard laboratory methods. All blood samples on which electrolytes were determined were withdrawn from a femoral artery. 


\section{EXPERIMENTS}

First, the state of the dog, secreting or fasting, was established. In those experiments where the animals were secreting, that is, in an active state of gastric digestion, food had been given by mouth at 8:00 a.m. In the dogs with pouches of the body of the stomach, the output into the pouch was measured hourly for the ensuing 2 to 4 hours. A flow of juice of low $\mathrm{pH}$ and increased volume, comparable to control days for that dog after feeding, was considered adequate proof of active secretion. In the dogs with an antral pouch, the only evidence obtainable of active gastric digestion was a drop in $\mathrm{pH}$ of the secretion.

In the experiments with animals in the fasting state, the last feeding had been given 24 to 48 hours previous to the day of experiment. Close control of the fasting state was necessary because of the occasional reappearance of active secretion, due presumably to a conditioned reflex. In the animals with the body pouch, a low volume output of juice of high $\mathrm{pH}$ was demonstrated for at least 2 hours.
Second, arterial blood was taken for control determinations of electrolytes. (This initial control was omitted in some of the later experiments.)

Third, the radioactive sodium, in isotonic, hypertonic, or hypotonic solution was introduced into the pouch. Fourth, blood was removed at intervals up to 2 hours for determination of radioactivity of the serum. On the last or middle sample, the total electrolyte partition was determined. Finally, the pouch was emptied, and the volume, $\mathrm{pH}$, pepsin, and electrolytes of the contents determined. The pouch was rinsed twice and the total recovery of radioactive sodium measured from contents and rinsings.

Three dogs with a pouch of the body of the stomach, and 2 with a pouch of the antrum, were used. The experiments were grouped as follows:

\section{Body pouch-Secreting state-Isotonic solution of radioactive sodium}

Seven experiments with an isotonic solution of $\mathrm{Na}^{2} \mathrm{Cl}$ were performed on 2 of the dogs with a pouch of the

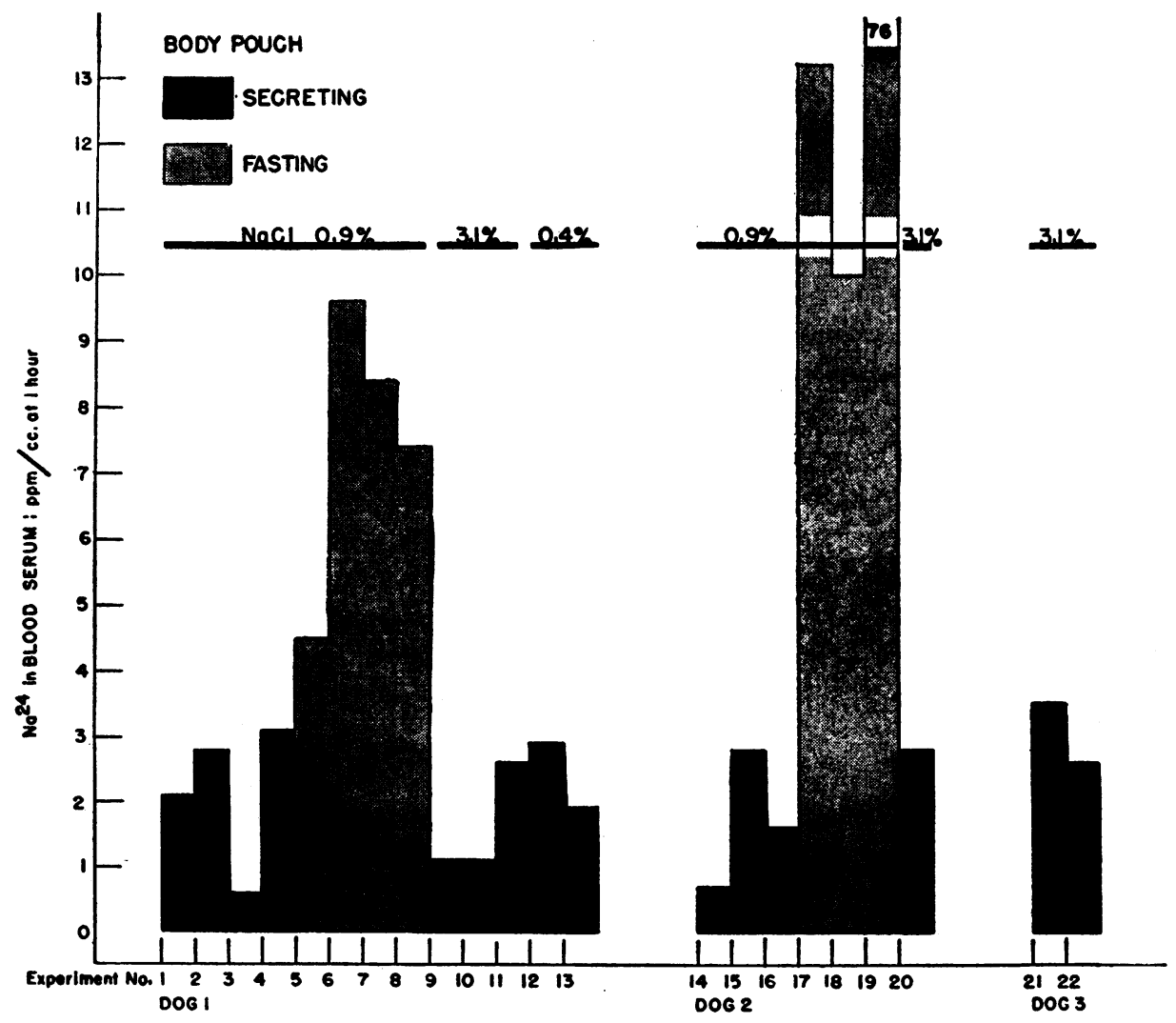

Fig. 1. The Concentration of $\mathrm{Na}^{2}$ in the Blood Serum One Hour After Its Introduction into the Pouches of the 3 Dogs with Pouches of the Body of the Stomach

In the experiments represented by the black blocks, the pouches were actively secreting hydrochloric acid; in those represented by the gray blocks, the dogs were fasting and the pouches were secreting a neutral to slightly acid juice. The percentage of the $\mathrm{Na}^{20} \mathrm{Cl}$ solution used in the various experiments is given at the upper half of the chart. 
body, during the secreting state. The results of the determinations on gastric juice and blood are given in Table I, experiment numbers 1 through 4, and 14 through 16. The concentration of radioactive sodium in the blood serum, one hour after the introduction of the sodium into the pouch, is shown graphically in Figure 1.

An appreciable concentration of radioactive sodium was found in the blood stream, 15 minutes after the introduc- tion of the sodium solution into the pouch. The concentration rose through the 1 or 2 hours of each experiment. The absolute amounts of radioactive sodium absorbed by the 2 dogs were approximately the same.

In order to determine if variations in electrolyte concentrations in the blood would exert any effect on the rate of absorption of sodium, the intake of chloride and sodium by mouth was altered during the days previous to the

TABLE II

The concentration of $\mathrm{Na}^{24}$ in the blood serum at one and 2 hours after its introduction into the pouches of the 2 dogs with antral pouches, and the chemical determinations on gastric contents and blood serum

Where two sets of figures are given for both gastric contents and blood serum, the top figure represents the determination on contents and blood removed immediately prior to the introduction of the $\mathrm{Na}^{24} \mathrm{Cl}$ solution; the bottom figure (in italics) represents the determination made on the contents and blood removed at the end of the experiment. Where only one figure is given for the blood, a single blood sample was removed in the middle of the experiment. Dog number 4: weight $17.3 \mathrm{kgm}$.; dog number 5 : weight $18.5 \mathrm{kgm}$.

\begin{tabular}{|c|c|c|c|c|c|c|c|c|c|}
\hline \multirow{3}{*}{$\begin{array}{l}\text { Experiment } \\
\text { number }\end{array}$} & \multirow{3}{*}{$\underset{\substack{\mathrm{NaCl} \text { concentration } \\
\text { State of pouch }}}{\cdot}$} & \multirow{2}{*}{\multicolumn{2}{|c|}{$\frac{\mathrm{Na}^{2}}{\text { Blood serum }}$}} & \multirow{3}{*}{$\begin{array}{c}\begin{array}{c}\text { Gastric } \\
\text { content }\end{array} \\
\mathrm{pH}\end{array}$} & \multicolumn{4}{|c|}{ Blood serum } & \multirow{3}{*}{ Date } \\
\hline & & & & & \multirow{2}{*}{$\mathrm{Cl}$} & \multirow{2}{*}{$\mathrm{CO}_{2}$} & \multirow{2}{*}{$\begin{array}{l}\text { Total } \\
\text { base }\end{array}$} & \multirow{2}{*}{$\mathrm{Na}$} & \\
\hline & & $60^{\circ}$ & $120^{\circ}$ & & & & & & \\
\hline $\begin{array}{c}\text { Dog } 4 \\
23\end{array}$ & $\begin{array}{l}0.9 \text { per cent } \\
\text { Secreting }\end{array}$ & p.p.m & $c c$. & & $\begin{array}{l}114 \\
112\end{array}$ & $\begin{array}{l}20 \\
23\end{array}$ & $\begin{array}{l}156 \\
161\end{array}$ & $\begin{array}{l}148 \\
149\end{array}$ & June 5,1941 \\
\hline 24 & Secreting & 2.0 & 2.8 & & 108 & 29 & 151 & 145 & October 10, 1941 \\
\hline 25 & Fasting & 14.1 & 14.9 & & 117 & 23 & 149 & 141 & October 1,1941 \\
\hline 26 & $\begin{array}{l}3.1 \text { per cent } \\
\text { Secreting }\end{array}$ & 12.5 & 16.0 & 2.5 & 112 & 23 & 152 & 144 & June 24, 1941 \\
\hline 27 & Fasting & 17.5 & 31.4 & & $\begin{array}{l}120 \\
114\end{array}$ & $\begin{array}{l}19 \\
21\end{array}$ & $\begin{array}{l}155 \\
162\end{array}$ & 144 & June 12, 1941 \\
\hline 28 & Fasting & 15.5 & 23.3 & $\begin{array}{l}6.6 \\
4.5\end{array}$ & 112 & 23 & 157 & 144 & July 8,1941 \\
\hline 29 & $\begin{array}{l}0.4 \text { per cent } \\
\text { Secreting }\end{array}$ & 3.6 & 4.1 & $\begin{array}{l}2.7 \\
2.0\end{array}$ & 110 & 28 & 152 & 143 & July 17,1941 \\
\hline 30 & Fasting & 7.5 & 8.8 & 2.5 & 110 & 24 & 151 & 143 & July 24, 1941 \\
\hline $\begin{array}{c}\text { Dog } 5 \\
31\end{array}$ & $\begin{array}{l}0.9 \text { per cent } \\
\text { Secreting }\end{array}$ & 19.2 & 58.5 & $\begin{array}{l}9.0 \\
7.8\end{array}$ & 118 & 27 & 155 & 148 & October 10, 1941 \\
\hline 32 & Fasting & 28.0 & 47.0 & & $\begin{array}{l}110 \\
114\end{array}$ & $\begin{array}{l}26 \\
26\end{array}$ & $\begin{array}{l}153 \\
155\end{array}$ & $\begin{array}{l}144 \\
148\end{array}$ & June 5, 1941 \\
\hline 33 & $\begin{array}{l}3.1 \text { per cent } \\
\text { Secreting }\end{array}$ & 55.0 & 68.5 & & $\begin{array}{l}106 \\
106\end{array}$ & $\begin{array}{l}32 \\
32\end{array}$ & $\begin{array}{l}162 \\
160\end{array}$ & $\begin{array}{l}150 \\
149\end{array}$ & June 12,1941 \\
\hline 34 & Secreting & 102.0 & 95.0 & 6.8 & 104 & 32 & 157 & 143 & July 8, 1941 \\
\hline 35 & Fasting & 83.0 & 68.0 & 7.4 & 96 & 31 & 153 & 140 & June 24, 1941 \\
\hline 36 & $\begin{array}{l}0.4 \text { per cent } \\
\text { Secreting }\end{array}$ & 42.7 & 54.5 & 3.2 & 108 & 31 & 161 & 149 & July 25,1941 \\
\hline 37 & Fasting & 62.5 & 32.6 & 5.5 & 114 & 24 & 155 & 147 & July 17, 1941 \\
\hline
\end{tabular}


several experiments. Since these dogs lose daily such large quantities of electrolytes, principally chloride but also some base, through the secretion into the pouch, it is easy to produce rapid changes in electrolyte concentrations in the body fluids. In these experiments, a range of blood chloride from 116 m.eq. to 68 m.eq., and total base from 168 m.eq. to 146 m.eq., was obtained. No significant difference in the absorption of $\mathrm{Na}^{24}$ was observed in spite of these wide variations.

\section{Body pouch-Fasting state-Isotonic $\mathrm{Na}^{24} \mathrm{Cl}$ solution}

Seven experiments with isotonic $\mathrm{Na}^{24} \mathrm{Cl}$ solution were performed with 2 dogs in the fasting state (the same dogs used in the first group of experiments). The results of the determinations on gastric juice and blood are given in Table I, experiment numbers 5 through 8 , and 17 through 19. The concentration of radioactive sodium in the blood serum, one hour after the introduction of the sodium into the pouch, is shown graphically in Figure 1.
With the mucous membrane of the pouch in the resting phase, there is a significant increase in the concentrations of the radioactive sodium in the blood serum over those found when the membrane is actively secreting hydrochloric acid. In dog 1 , the average concentration in the serum at one hour was 7.5 p.p.m. in the resting state, against 2.2 p.p.m. when secreting; in $\operatorname{dog} 2$, the average concentration at one hour was 33.2 p.p.m. resting, against 1.7 p.p.m. secreting. In the latter animal, the fasting average was weighted by one observation considerably higher than the other two. This single observation was the highest concentration in the serum recorded in any of the experiments with a pouch of the body of the stomach.

As in the experiments in group 1, shifts in electrolyte partition of the blood serum were obtained by altering the salt intake. The chloride observations varied from 108 to 82 m.eq., the total base from 157 to 144 m.eq. No significant correlation was determined between any of the

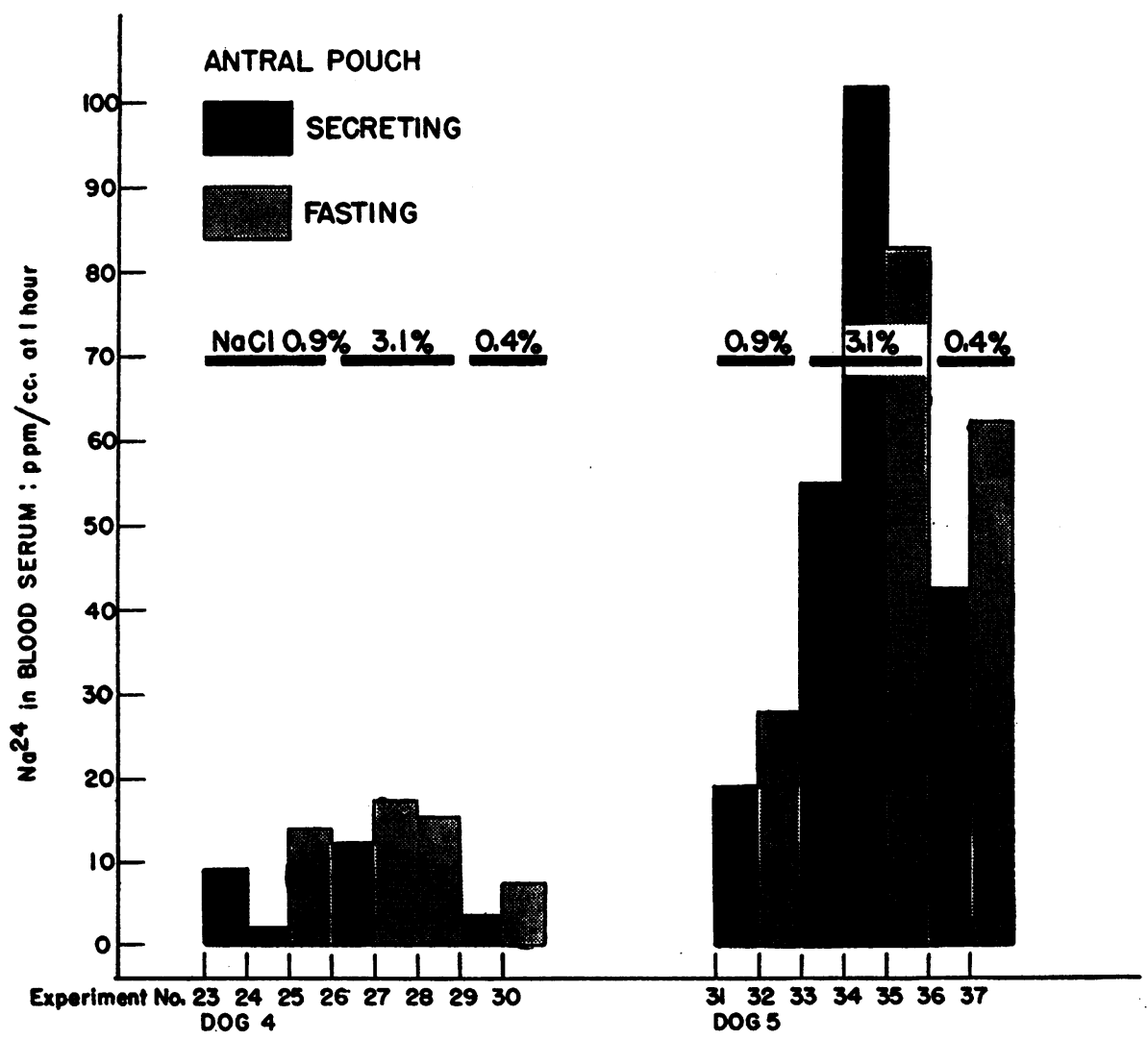

Fig. 2. The Concentration of $\mathrm{Na}^{24}$ in the Blood Serum One Hour After Its Introduction into the Pouches in the 2 Dogs with Pouches of the Antrum of the STOMACH

In the experiments represented by the black blocks, the dog's stomach was in an active state of digestion; in those represented by the gray blocks, the dogs were fasting. The percentages of the $\mathrm{Na}^{24} \mathrm{Cl}$ solution used in the various experiments is given at the upper half of the chart. (The scale of the sodium concentration is ten times that used in Figure 1.) 
electrolyte concentrations produced and the concentration of radioactive sodium in the serum.

\section{Body pouch-Secreting state-Hypo- and hypertonic $\mathrm{Na}{ }^{29} \mathrm{Cl}$ solution}

Four experiments using 0.4 per cent $\mathrm{Na}^{2 \mathrm{Cl}}$ solution were made on dogs 1 and 3 ; and 4 using 3.1 per cent were made on dogs 1 and 2. The dogs were in the secreting state in all experiments. The data are recorded in Table I, experiment numbers 9 through 13 , and 20 through 22 . The concentration of radioactive sodium found in the blood serum, one hour after the introduction of the sodium, is shown in Figure 1.

There was no significant difference in the concentration of radioactive sodium found in the serum, in spite of the wide range in osmotic tension. The concentrations were comparable to those found in the experiments in group 1, with isotonic saline in the secreting state.

\section{Antral pouch}

Fifteen experiments were made on 2 dogs with an antral pouch, dogs 4 and 5 . The data are given in Table II; the concentration of radioactive sodium found in the blood serum, one hour after its introduction into the pouch, is shown in Figure 2 (the scale is 10 times that of Figure 1).

In 5 experiments, the radioactive sodium was in isotonic chloride solution; in 2 of these, the dogs were fasting (experiment numbers 25 and 32 ), and in the other 3 , secreting (experiment numbers 23,24, and 31). In 6 experiments, 3.1 per cent sodium chloride solution was used, with half in the secreting state (experiment numbers 26,33 , and 34 ), and half in the fasting (experiment numbers 27,28 and 35 ). Hypotonic saline, 0.4 per cent, was put in the pouch for the remaining 4 experiments (numbers 29,30,36, and 37), each dog being tested in the secreting and fasting states.

In these experiments, approximately 10 times the concentration of radioactive sodium was found in the serum compared with that in dogs with a pouch of the body of the stomach. In all except one experiment (number 34), the concentration in the serum was greater when the dogs were fasting. The differences between the fasting and secreting experiments are, however, not as great as those encounterd with the body pouches.

There is an apparent effect of the osmotic pressure of the sodium solution in these experiments, in contrast to those with the body pouches; the absorption from the hypertonic solution is slightly greater. The differences however are not significant.

If the difference in the surface area of the mucous membrane of the two types of pouch is considered, the relative absorption of sodium from the antrum is increased. The surface area of the antral pouch is approximately one-tenth that of the body pouch. The absorption of sodium per unit of surface area is therefore 100 times greater from the antral than from the body pouch.

\section{DISCUSSION}

The absolute amounts of radioactive sodium absorbed from the stomach are small but not insignificant. From 1 to 7 per cent of the sodium introduced into a pouch of the body area is absorbed in one hour. From 1 to 50 per cent of the sodium introduced into the antral pouch is absorbed during the same period. Sodium is secreted with the gastric juice. It is obvious that, in any study of gastric secretion, the reabsorption of base must be evaluated. The fluid within a pouch of the stomach is the resultant of secretion and reabsorption, and represents contents, not secretion.

It is in keeping with absorption elsewhere in the gastro-intestinal tract that more sodium should be absorbed from the antrum of the stomach than from the body. The absorbing surfaces of the intestinal tract are bathed by a neutral or alkaline fluid. The contents of an antral pouch are neutral or slightly alkaline. In any future consideration of absorption from the stomach, it will be necessary to differentiate between the neutral-alkaline antrum and the acid body. A whole stomach pouch is hardly a suitable medium for the study of secretion or absorption.

The removal of basic ions from the gastric lumen, and their transport across the parietal cell into the body fluids, might be an integral part of the mechanism by which the hydrogen ion is secreted in the reverse direction. If the sodium ion were so transported, more sodium should have been absorbed during the secreting state. These experiments, therefore, tend to exclude such a mechanism for the formation of hydrochloric acid.

It is unknown which cell secretes or reabsorbs sodium. It is inconceivable that the parietal or acid secreting cells could allow a free passage to sodium during the active secretion of acid. A possible explanation of our observations is that the parietal cells become pervious to sodium when they are resting. On the other hand, it is not necessary for the parietal cells to play any role in the reabsorption of the sodium. All of this ion could pass through the pepsin or mucin secreting cells. A smaller amount might well be absorbed during the active secretion of pepsin, which occurs during the secretory phase of the stomach. Such a theory does not hold for the mucin cells, since 
the secretion of mucin does not run parallel to that of acid and pepsin.

The lack of effect of varying the osmotic pressure on the sodium absorption suggests that the absorption mechanism is not one of a simple Donnan equilibrium.

\section{SUMMARY AND CONCLUSIONS}

The absorption of radioactive sodium has been observed in dogs from a pouch of either the body or antrum of the stomach.

Radioactive sodium is absorbed in small but significant quantities from the body or acid secreting area. Two to three times as much is absorbed when the mucosa is in the resting rather than in the secreting state. The gastric antrum absorbs 100 times as much per unit of surface area as the acid secreting body. Whether the stomach is fasting or secreting makes less difference to the absorption from the antrum than to the absorption from the body.

Variations in the osmotic pressure of the sodium solution and in electrolyte concentrations in the blood serum, within the limits observed, had no significant effect on the rate of absorption of the sodium.

The concept that the fluid in an isolated pouch of the stomach represents secretion is obsolete. It is suggested that the antrum plays a preponderant role in any observed absorption from the whole stomach.

\section{BIBLIOGRAPHY}

1. Cope, O., and Brenizer, A. G., Jr., Gastric secretion. IV. The influence of osmotic pressure of gastric contents on the volume of gastric secretion. (To be published.)

2. Best, C. H., and Taylor, N. B., The Physiological Basis of Medical Practice. The Williams and Wilkins Company, Baltimore, 1939.

3. Eisenman, A. J., Smith, P. K., Winkler, A. W., and Elkinton, J. R., The transfer of ions across the stomach wall, studied by means of radioactive isotopes. J. Biol. Chem., 1941, 140, xxxv.

4. Cope, O., Blatt, H., and Ball, M. R., Gastric secretion. III. The absorption of heavy water from pouches of the body and antrum of the stomach of the dog. J. Clin. Invest., 1943, 22, 111.

5. Cope, O., McMahon, C. E., Hagströmer, A., and Thompson, R. H., Gastric secretion. I. A new gastric pouch with a non-leaking stoma and an intact nerve supply; description of a two stage technic used on the dog. Arch. Surg., 1940, 40, 717.

6. Gregersen, M. I., and Stewart, J. D., Simultaneous determination of the plasma volume with T-1824, and the "available fluid" volume with sodium thiocyanate. Am. J. Physiol., 1939, 125, 142.

7. Cohn, W. E., and Cohn, E. T., Permeability of red corpuscles of the dog to sodium ion. Proc. Soc. Exper. Biol. and Med., 1939, 41, 445.

8. Kaltreider, N. L., Meneely, G. R., Allen, J. R., and Bale, W. F., Determination of the volume of the extracellular fluid of the body with radioactive sodium. J. Exper. Med., 1941, 74, 569. 